\title{
Parasitic infection of the diatom Guinardia delicatula, a recurrent and ecologically important phenomenon on the New England Shelf
}

\author{
Emily E. Peacock, Robert J. Olson, Heidi M. Sosik ${ }^{*}$ \\ Biology Department, Woods Hole Oceanographic Institution, Woods Hole, Massachusetts 02543, USA
}

ABSTRACT: Plankton images collected by Imaging FlowCytobot from 2006 to 2013 at the Martha's Vineyard Coastal Observatory (Massachusetts, USA) were used to identify and quantify the occurrence of the diatom Guinardia delicatula and of a parasite that seems specific to this host. We observed infection with morphological stages that appear similar to the parasite Cryothecomonas aestivalis. Our results show that events during which infection rates exceed $10 \%$ are recurrent on the New England Shelf and suggest that the parasites are an important source of host mortality. We document a significant negative relationship between bloom magnitude and parasite infection rate, supporting the hypothesis that the parasites play a major role in controlling blooms. While G. delicatula is observed during all seasons, the infecting stages of the parasite are abundant only when water temperature is above $4{ }^{\circ} \mathrm{C}$. The anomalously warm water and small G. delicatula bloom during the winter of 2012 provided evidence that parasites can be active through winter if temperatures remain relatively high. As climate change continues, winter periods of water below $4^{\circ} \mathrm{C}$ may shorten or disappear in this region, suggesting that parasite effects on species such as G. delicatula may increase, with immediate impacts on their population dynamics.

KEY WORDS: Phytoplankton - Diatom - Parasite . Imaging flow cytometry · MVCO • Guinardia delicatula · Cryothecomonas aestivalis

Resale or republication not permitted without written consent of the publisher

\section{INTRODUCTION}

Parasites of phytoplankton are potentially influential drivers of phytoplankton bloom dynamics, but concrete, quantitative evidence is difficult to acquire.

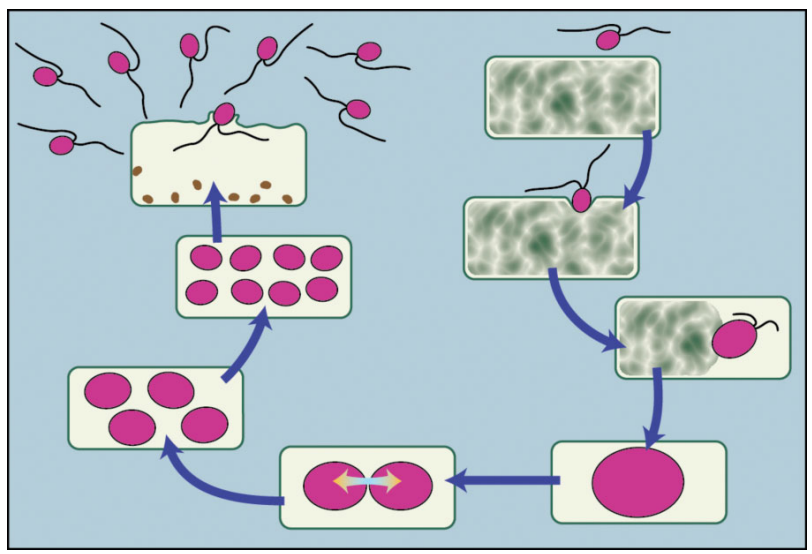

Nanoflagellate parasites that consume cytoplasm and reproduce inside diatom host cells have important impacts on coastal blooms.

Image: Jack Cook (WHOI)

While the idea has been recognized for decades (Canter \& Lund 1948), limited spatial-temporal resolution associated with traditional sampling techniques makes it challenging to observe population effects of parasites adequately, and sample preservation often prevents identification of parasite species. Parasites and pathogens that are known to impact a wide variety of phytoplankton hosts include viruses documented to restrict or terminate Phaeocystis blooms (Brussaard et al. 2005), fungi that can influence bloom dynamics and succession in diatoms (Ibelings et al. 2011, Sime-Ngando 2012), dinoflagellates that infect other dinoflagellates (Coats \& Park 2002, Chambouvet et al. 2008), and bacteria that infect dinoflagellates and may be useful for toxic bloom control (Kim et al. 2008). Most knowledge of 
the biology of diatom parasites has come from investigation of isolates in culture (Drebes \& Schnepf 1982, 1988, 1998, Schnepf et al. 1990, Drebes et al. 1996, Kühn et al. 1996). In contrast to the view that diatoms are typically grazed by macrozooplankton, these studies identified and described organisms that consume diatoms but are just a fraction of the size of the diatoms themselves. All parasites complete part of their life cycle in or on their host; while typical parasites do not kill their hosts, these diatom studies documented lethal parasites or parasitoids that actually consume host cells during their development. Tillmann et al. (1999) were able to extend this culture work to show that in a natural system, diatom losses associated with these parasitoids can be important. They were able to document and quantify an intensive infection of Guinardia delicatula and G. flaccida by several parasites in German coastal waters. Substantial investment in expert taxonomy and manual microscopy was required to reach these findings. Because few research programs can meet these demands, our knowledge of how widespread and recurrent these types of phenomena may be in a range of natural waters has remained limited.

New observational approaches have the potential to address some of these limitations. Molecular analyses that can be used to identify and quantify hosts, parasites, and pathogens (including fungi, viruses, bacteria, or protists) are an important avenue forward (Chambouvet et al. 2008, Gachon et al. 2010). While the potential of automated in situ genetic characterization exists (Scholin et al. 2006), at present these kinds of analyses still typically suffer from the limitations associated with discrete sampling. Automated imaging-in-flow cytometry (Sieracki et al. 1998, Olson \& Sosik 2007, Sosik \& Olson 2007) offers a complementary approach. While the cell images produced with these approaches cannot provide the taxonomic detail and definitive identification possible with molecular characterization of parasites, they have potential to meet needs for temporally and spatially resolved studies of natural populations of interacting hosts and parasites.

Time series observations with instruments that combine flow cytometry and microscopy can provide new insights into many aspects of community dynamics in natural systems. Because it is fully automated, submersible, and resistant to bio-fouling, Imaging FlowCytobot (IFCB; Olson \& Sosik 2007) can be deployed for 6 mo or longer without maintenance and is now providing time series observations at a number of coastal locations (Campbell et al. 2010, 2013, Sosik et al. 2010, Brosnahan et al. 2013). The longest of these time series is underway at the Martha's Vineyard Coastal Observatory (MVCO) on the New England Shelf. IFCB was first deployed at MVCO in June of 2006 and since then has been almost continuously collecting images of phytoplankton and other particles in the size range $\sim 5$ to $150 \mu \mathrm{m}$. At MVCO, IFCB is deployed side-by-side with FlowCytobot (FCB; Olson et al. 2003), which is optimized to analyze picoplankton and small nanoplankton $(\sim 1$ to $10 \mu \mathrm{m})$. Together the 2 instruments generate an unprecedented, continuous and high-resolution phytoplankton time series that offers capabilities not feasible with traditional microscopy and discrete samples (Sosik et al. 2010). This time series provides insights into life cycles and growth patterns of picocyanobacteria, diatoms, dinoflagellates, other types of phytoplankton, and some types of protozoa (e.g. herbivorous or mixotrophic ciliates). The vast quantity of images in this multi-year time series provides an exceptional opportunity to characterize the occurrence of different types of plankton-plankton interactions, including parasites of phytoplankton.

Here we present details of interactions between the centric diatom $G$. delicatula and a nanoflagellate parasite/parasitoid similar to Cryothecomonas aestivalis as described by Drebes et al. (1996), and their recurring interactions as documented by IFCB throughout the time series from June 2006 to September 2013. While many species are present in the MVCO time series and blooms are typically multispecies events, G. delicatula represents one of the greatest contributors to phytoplankton biomass, which is also true in another temperate coastal time series (Schlüter et al. 2012). From an ecological perspective, major questions persist concerning the factors that promote diatom bloom events and determine how long a bloom lasts. Schlüter et al. (2012) have recorded $45 \mathrm{yr}$ of $G$. delicatula blooms showing a predominantly summer bloom with decadal scale changes in duration and timing of onset; in our shorter time series, we also see some variation, but with a predominantly winter bloom. The nanoflagellate parasite of $G$. delicatula is recognizable throughout our data set during 2 of its presumed 3 life stages due to the distinct morphology within $G$. delicatula frustules during infection. Our results indicate that the parasite commonly contributes to the decline of G. delicatula blooms. This finding suggests that diatom parasites may be more prevalent than previously considered and presents quantitative evidence of parasite attacks as an important influence on the fluctuation of a prominent diatom species in coastal temperate waters. 


\section{MATERIALS AND METHODS}

\section{Study site}

MVCO is a cabled facility located off the south shore of the island of Martha's Vineyard (Massachusetts, USA), which provides shore-based power and high speed 2-way communications to an undersea node at a depth of $12 \mathrm{~m}$, and to a tower structure $3 \mathrm{~km}$ offshore in $15 \mathrm{~m}$ water depth (Austin et al. 2000, Fredericks et al. 2006). The offshore tower is located at $41^{\circ} 19.5^{\prime} \mathrm{N}, 70^{\circ} 34.0^{\prime} \mathrm{W}$ and this is where IFCB has been repeatedly deployed at a depth of $4 \mathrm{~m}$ below mean water level, with water sampling conducted at the instrument depth. Deployments between 2006 and 2009 were conducted with a single instrument, with some extended gaps during maintenance periods. Beginning in 2010, 2 instruments were available, providing the capability for same-day turnaround and much reduced data gaps. In total, data were collected from 20 IFCB deployments ranging from 3 to 350 d (mean 120 d after 2006) from 2006 through 2013. Core measurements at the MVCO facility provide a broad suite of publicly available meteorological and hydrographic data (www.whoi. edu/mvco), including temperature (Sea-Bird Electronics, MicroCAT) measured at the undersea node, which is located approximately $1.5 \mathrm{~km}$ from the offshore tower. Temperature measurements (Sea-Bird Electronics, MicroCAT) were also made during most of the time period at the same depth $(4 \mathrm{~m})$ and location (offshore tower) as IFCB sampling.

\section{IFCB}

Details of the IFCB instrument and data collection have been described previously (Olson \& Sosik 2007). Briefly, IFCB uses a combination of video and laser-based flow cytometric technology to both capture images of nano- and microplankton and measure their chlorophyll fluorescence. The images obtained with IFCB are of high enough resolution $(\sim 1 \mu \mathrm{m})$ that many plankton taxa can be recognized to genus or even species (Sosik \& Olson 2007). Particles can be analyzed at rates up to $12 \mathrm{~Hz}$, and observed particle concentrations typically produce on the order of 10000 fluorescence-triggered events $\mathrm{h}^{-1}$ during deployments at MVCO. IFCB was configured to analyze a new $5 \mathrm{ml}$ sample of seawater approximately every $20 \mathrm{~min}$. Since IFCB uses fluorescence triggering for image capture, a high proportion of the stored images contain phytoplankton cells, colonies, or chains. Real-time image analysis on IFCB is used to segment images, and only regions of interest (portions of the camera field that contain a target) are stored for subsequent analysis. The full data set of IFCB images is accessible at http://ifcb-data.whoi. edu/mvco. We have shown previously that the IFCB imaging approach provides similar results to enumeration with traditional manual microscopy for a variety of phytoplankton species including Guinardia delicatula (Olson \& Sosik 2007).

\section{Data analysis}

Our routine analysis of the image data set starts with automated image processing and classification following the approach described by Sosik \& Olson (2007), with the modification that we currently use an assemblage of decision trees constructed following the random forest approach of Breiman (2001) in place of the support vector machine described previously. The current automated classifier has 50 categories, including 28 diatom genera or species (including G. delicatula), as well as dinoflagellate taxa, miscellaneous nanoplankton, ciliate taxa, and detritus. We have previously shown that this automated classification approach is highly accurate (>90\% correct identifications) for many diatom taxa including G. delicatula (Olson \& Sosik 2007). While the requirement for taxonomic expertise to define the classes of interest is similar to that needed for manual microscopy, the image archive provides infinite flexibility to adjust and refine classifications in response to new information or applications; this can be done long after the sampling and initial analysis is complete. The approach also allows reanalysis or more detailed retrospective analysis as topics of interest emerge. Subsequent to automated classification, we take advantage of this flexibility to conduct routine computer-assisted manual verification and correction of approximately $3 \mathrm{~h}$ of observations from each month, selected such that there is at least one verified time point for each 2 wk interval throughout the time series. In this verification step, we resolve errors made by the automated classifier and subdivide selected categories into more finely resolved groups. The manually corrected $3 \mathrm{~h}$ of data represent $\sim 30 \mathrm{ml}$ of water, and contain anywhere from 5000 to 100000 images of phytoplankton, detritus, and microzooplankton. As part of this step, for the G. delicatula category, cells and chains with visible signs of internal parasite infection were manually annotated. As described by Drebes et al. (1996), the first life cycle stage of the parasite is a motile, colorless 
flagellate, either outside the host or inside the host before food uptake. Free cells of this stage are not likely to be imaged by IFCB since they do not contain chlorophyll (though they may have sometimes been included in a G. delicatula image, e.g. Fig. 1a). Neither these free swimming flagellates nor small attached cells have distinctive enough morphology to be certain about their identity as parasites; therefore they were not considered in this analysis.

For this study, some additional manual classification was carried out focused only on G. delicatula and $G$. delicatula with parasites to increase resolution during parasite events discovered during the routine analyses. For further analyses, concentrations in each category are presented after daily binning (i.e. sum of observed counts in all 20 min time points divided by total volume of seawater analyzed in the time points during a single day). Only time points that were manually verified (after initial automated classification) were included in these daily binned estimates and presented in this study. Misclassification errors associated with the automated analysis were removed from all results presented and discussed below. Whether by automated or manual classification, each count in our data set represents one region of interest or image. An image may have a single cell, or a long chain or colony of cells, depending on the species. To constrain biomass contributions, we conduct further automated analysis to estimate the biovolume of cells in the images following the approach described by Moberg \& Sosik (2012), and then estimate carbon content from biovolume following the relationships determined by Menden-Deuer \& Lessard (2000) from meta-analysis of extensive culture studies. For the purpose of characterizing infection, however, any image containing even one cell of parasite attack was counted as infected. This might be a single cell, a long chain with one cell attacked, or a long chain with multiple attacks.

Distinct bloom events for $G$. delicatula were identified on the basis of chain concentration. We defined important events according to contiguous periods when daily-binned concentration exceeded 2 chains $\mathrm{ml}^{-1}$ and the peak was at least 5 chains $\mathrm{ml}^{-1}$. This analysis resulted in 12 identified events over the entire time series. Three events during 2008 occurred during periods with data gaps such that the events are incompletely characterized, so these were excluded from subsequent analyses. For each event, total bloom magnitude $(B)$ was computed by integrating (trapezoidal method) time-dependent abundance $(C(t))$ from the time that daily concentration first exceeded $2 \mathrm{ml}^{-1}\left(t_{\text {start }}\right)$ until it dropped below that concentration again and stayed below for at least $1 \mathrm{wk}\left(t_{\text {end }}\right)$ :

$$
B=\int_{t_{\text {start }}}^{t_{\text {end }}} C(t) \mathrm{d} t
$$

The correlation coefficient (r) between bloom magnitude and infection rate (average during each event) was computed to determine the amount of variance explained $\left(\mathrm{r}^{2}\right)$. We tested for significance of a negative relationship between these quantities with a 1tailed $t$-test. We tested for outliers in this relationship with a 2-tailed $t$-test applied to externally Studentized residuals (i.e. each residual divided by the standard deviation estimated with that point excluded) from the least squares linear regression.

\section{RESULTS}

During routine manual classification of IFCB images, we observed Guinardia delicatula chains with unusual cytoplasm and chloroplast morphology in some cells, while other cells in the same chain looked normal. Upon closer examination of the affected chains, we observed what appeared to be the second and third parasitic stages of Cryothecomonas aestivalis as described by Drebes et al. (1996; Fig. $1 \mathrm{~b}-\mathrm{k})$. The second stage, in which a trophont stage of the parasite gradually phagocytizes the diatom protoplast (Drebes et al. 1996), is readily visible in IFCB images (Fig. 1b,c). The third stage, digestion accompanied by cell division, is the most commonly found stage in the images (Fig. 1d-k). Initially, one flagellate consumes all of the protoplast within a cell (Fig. 1d,e) and then produces 2, 4, 8, or more daughter cells (Fig. 1f-k). Multiple infections are also possible within one $G$. delicatula chain (Fig. 1j,k). Previous parasitic attack (completed when the parasite offspring exit the frustule) is evident when empty frustules contain fecal remains that were excreted from the parasite before the last cell division (Drebes et al. 1996; Fig. 1k). In culture studies of $C$. aestivalis, the entire vegetative life cycle took 18 to $20 \mathrm{~h}$ (Drebes et al. 1996). Since higher-resolution microscopy or genetic analysis would be required to confirm the identity of the parasites in this study, we can conclude only that the parasites we observed are similar to $C$. aestivalis in appearance, lifecycle, and host. We focus the rest of the analysis on how they affect the bloom dynamics of $G$. delicatula in our study area and consideration of the conditions that may control parasite impact. 
Seven years of image data from mid-2006 to late 2013 show a winter bloom of G. delicatula every year, usually starting after 1 January and peaking in February or March (Fig. 2a,b). In addition, most years have an occurrence of $G$. delicatula in the summer or fall, which is usually (but not always) smaller than the winter blooms. The parasite of $G$. delicatula (which we detect only when $G$. delicatula is present), is abundant during many but not all of the blooms (Fig. 2c). There are repeated occurrences when infected chains represent greater than $10 \%$ of the observed G. delicatula population (Fig. 2b), and infection rates sometimes exceed $30 \%$ (Fig. 3).

Average daily water temperature from the area ranged from $-0.16^{\circ} \mathrm{C}$ in the coldest winter (2009) to
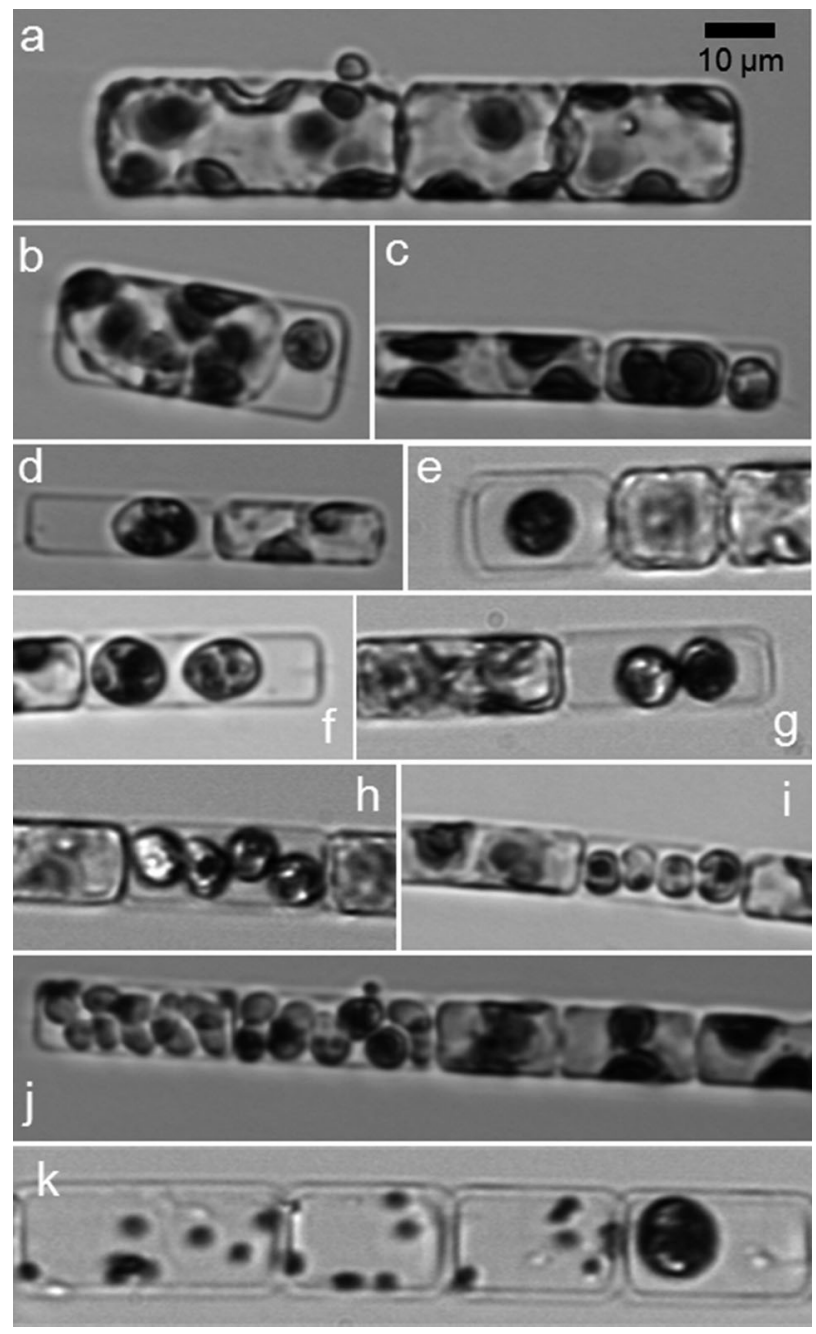

Fig. 1. Imaging FlowCytobot images of the parasite stages during infection of Guinardia delicatula: (a) possible external flagellate; $(b, c)$ trophont initiates consumption of protoplast; $(d, e)$ trophont at the end of nutritive phase; $(f, g) 2$ parasite daughter cells after first cell division; (h,i) 4 daughter cells; (j) 8 or more daughter cells; (k) empty frustules containing fecal remains $21.5^{\circ} \mathrm{C}$ in the warmest summer (2012) (Fig. 2d). The winter of 2011-2012 represents an anomaly, only dropping to $3.6^{\circ} \mathrm{C}$, while the next warmest winter was 2007-2008, with a temperature minimum of $1.9^{\circ} \mathrm{C}$. The data set spans substantive inter-annual variability in both the arrival date and the duration of cold $\left(<4^{\circ} \mathrm{C}\right)$ water in winter (Fig. $\left.2 \mathrm{~d}\right)$. While there is some temperature stratification in summer and early fall $\left(\sim 0.5-1^{\circ} \mathrm{C}\right)$, temperature patterns are very similar between $4 \mathrm{~m}$ observations near IFCB and bottom depth (12 m node) observations. We used the bottom record for further analyses and comparison to IFCB observations because it is more complete across the full study time period.

\section{DISCUSSION}

Parasitic interactions in the phytoplankton may be common and varied (Van Donk 1989, Coats \& Park 2002, Park et al. 2004, Montagnes et al. 2008, Gachon et al. 2010, Ibelings et al. 2011), but they have been difficult to study in a quantitative manner in natural systems. We have taken advantage of a cabled observatory facility (MVCO) to carry out extended time series observations with IFCB of a particular parasite-host relationship in waters of the New England Shelf. The diatom host, Guinardia delicatula, is a recurrent and important contributor to total phytoplankton biomass in this system (Fig. 2a,b). While we cannot be certain about the identity of the parasite observed in our time series, it exhibits characteristics that are entirely consistent with morphological and life cycle properties described for Cryothecomonas aestivalis by Drebes et al. (1996). Interestingly, while G. delicatula always occurs in mixed assemblages that include a number of other diatom taxa, we almost never observed this or any similar parasite in association with other diatoms even when the rate of infection in G. delicatula was very high, the only exception being very rare instances of possible infection in other species of the same genus, viz. G. flaccida and G. striata. This level of specificity in the parasite-host relationship echoes findings of Tillmann et al. (1999) in the North Sea and culture work of Drebes et al. (1996).

Our extended time series shows definitively that parasite infection is a recurrent feature of G. delicatula blooms, and further suggests that infection is ecologically important. Infection rates exceeding $10 \%$ occur in every year of the record, most commonly in late fall or early winter, but also sometimes in summer (Fig. 2b). While previous studies did not address 
multi-year recurrence, the high infection rates and aspects of the seasonality we observe are consistent with reports from the North Sea (Drebes et al. 1996, Tillmann et al. 1999). Since the parasite life cycle is likely to be complete in less than $24 \mathrm{~h}$ and results in complete loss of the host cell (Drebes et al. 1996), multi-day events with infection rates as high as 10 to $30 \%$ strongly support the idea that this is a source of host mortality that can rival that of zooplankton grazing.

We further examined our data set to investigate what conditions are favorable to the presence of the parasite and what effect the parasites may have on G. delicatula population dynamics. We identified 9 events of high parasite infection ( $>2 \mathrm{~d}$ with $>10 \%$ of
G. delicatula chains infected). Notably, the largestamplitude G. delicatula blooms (i.e. late winter 2010, 2011, and 2013) occurred at times when parasites were minimal or absent (Fig. 2). While there were occasional observations of parasites when the water was colder than $4^{\circ} \mathrm{C}$ (Figs. $2 \& 3$ ), all of the parasite events began when temperature was above $4^{\circ} \mathrm{C}$. The few cases when parasites persisted after water temperature dropped below $4^{\circ} \mathrm{C}$ appeared to be associated with earlier high rates of infection and periods when temperatures lingered just below or fluctuated around $4^{\circ} \mathrm{C}$ (Fig. 2, see also Fig. 3b,d,i).

The high infection rate events reveal a variety of scenarios, depending on whether $G$. delicatula was already established when the parasites appeared
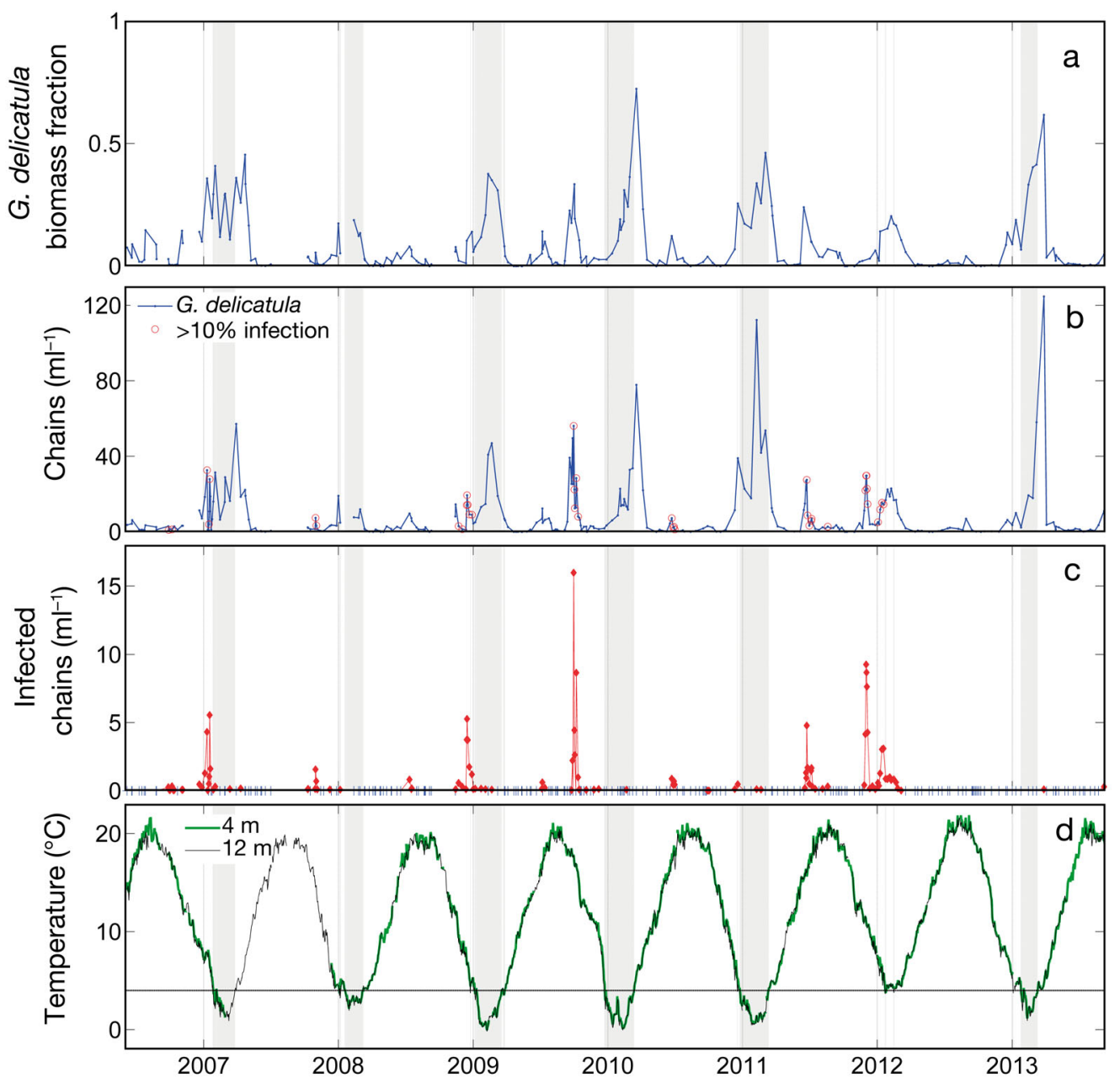

Fig. 2. Multi-year time series at Martha's Vineyard Coastal Observatory, with grey bars highlighting time periods when water temperature was $<4^{\circ} \mathrm{C}$. (a) Guinardia delicatula as a fraction of total phytoplankton biomass (considering cells with equivalent spherical diameter $>10 \mu \mathrm{m}$ ). (b) Abundance of $G$. delicatula chains; red circles indicate days with $>10 \%$ of chains containing at least 1 infected cell. (c) Occurrence of G. delicatula chains containing parasites or fecal remains; filled red diamonds indicate presence of parasites and blue ticks mark days that were manually inspected, but no parasites were found. (d) Water temperature at 4 and $12 \mathrm{~m}$ depths, with horizontal line at $4^{\circ} \mathrm{C}$. In all panels, the absence of lines connecting adjacent data points indicates gaps of $30 \mathrm{~d}$ or longer in the observational records 

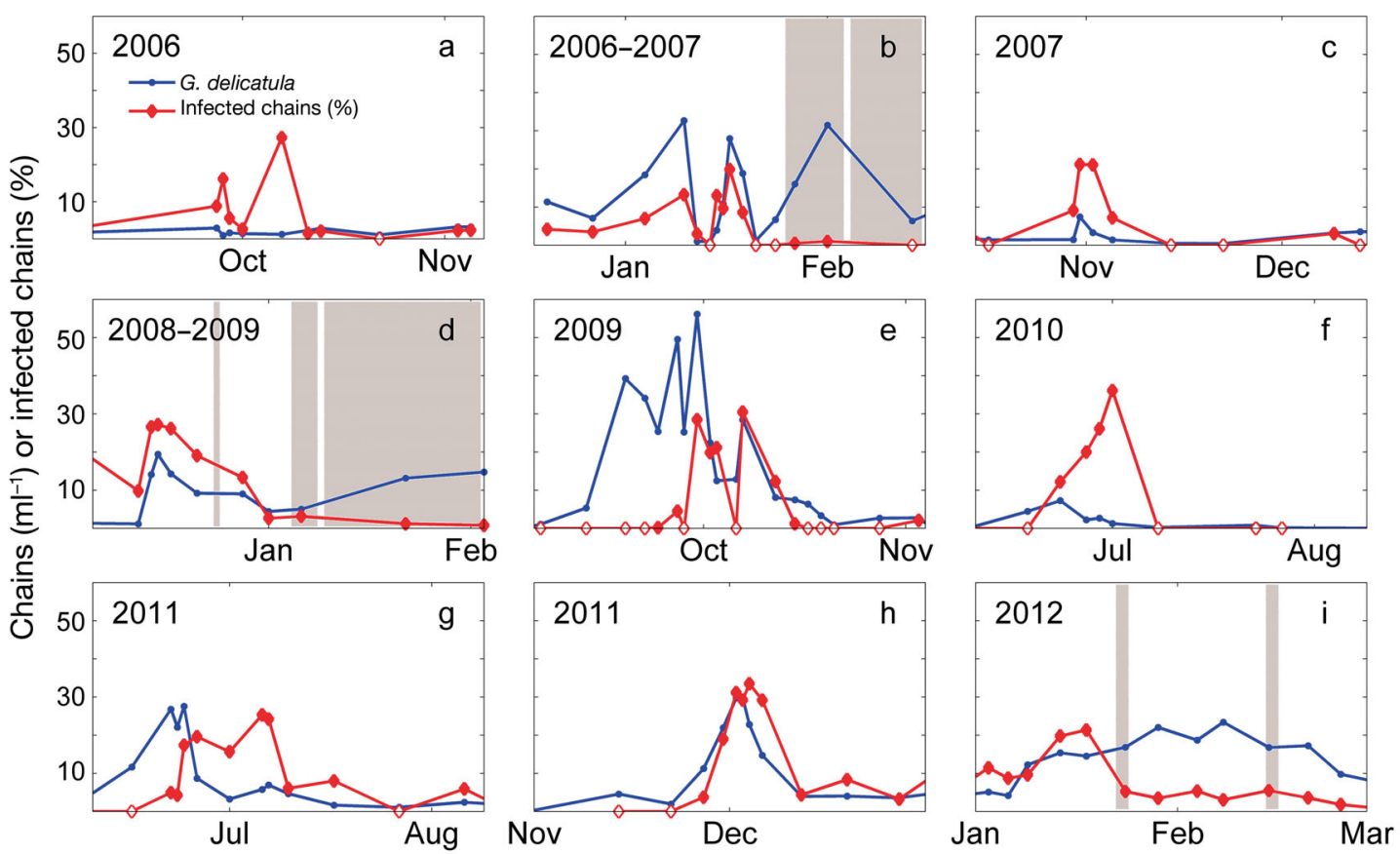

Fig. 3. Two-month time series highlighting events of high parasite infection ( $>2 \mathrm{~d}$ with $>10 \%$ of Guinardia delicatula chains infected). Grey regions highlight time periods when water temperature was $<4^{\circ} \mathrm{C}$. Blue lines indicate the number of $G$. delicatula chains $\mathrm{ml}^{-1}$. Filled red diamonds indicate days with detected parasite presence, while empty red diamonds mark days when images were manually inspected for parasites, but none were found

and on the water temperature during the event (Fig. 3). In all 3 cases of parasite attack in early winter, when the water temperature dropped below $4^{\circ} \mathrm{C}$ the parasites declined while $G$. delicatula increased (Fig. 3b,d,i). December 2008 (Fig. 3d) and winter 2012 (Fig. 3i) are cases where the water temperature hovered around $4^{\circ} \mathrm{C}$. In 2008 , the parasites persisted through the beginning of winter, and then declined when the water reached more typical winter temperatures. In 2012, when water temperature barely dipped below $4^{\circ} \mathrm{C}$, the parasites were present for the entire season (Fig. 3i).

The remaining parasite scenarios all occurred while the water was well above $4^{\circ} \mathrm{C}$. On several occasions $G$. delicatula was fairly well established in the summer or fall and then declined with the onset of parasite attack (Fig. 3e,g). For example, in October 2009, the concentration of G. delicatula reached levels often seen during winter blooms. After a few weeks, the number of chains infected with parasites also increased and then the G. delicatula population plummeted (Fig. 3e). At other times, parasites were observed nearly simultaneously with the first host cells and the event was small and brief (Fig. 3a,c,f). Late in 2011, the G. delicatula winter bloom appeared to get an early start, only to be curtailed by parasite infection (Fig. 3h). Once host levels dropped below 10 chains $\mathrm{ml}^{-1}$, infection rates dropped dramatically and the host maintained low levels until a second modest bloom was able to take hold and persist for 2 mo in early 2012 (Fig. 3i).

The infection patterns we observed in the time series strongly suggest a role for temperature in regulating parasite occurrence. It is expected that high infection rates cannot occur unless host abundances are elevated, but this is apparently not a sufficient condition for infection since many periods of high host abundance have little or no infection (Fig. 2). The highest infection rates we observed were $\sim 30 \%$ of $G$. delicatula chains (at least one infected cell). These high rates occurred when hosts chains were present at $>2 \mathrm{ml}^{-1}$ and usually $>5 \mathrm{ml}^{-1}$. Notably, they also always occurred when water temperature was $>4^{\circ} \mathrm{C}$ (Fig. 4). Low or undetectable presence of parasites during warmer periods was typically associated with low host abundance (i.e. points near the $x$-axis in Fig. 4 tend to have a low host concentration when $\mathrm{T}>$ $4^{\circ} \mathrm{C}$ ). Furthermore, when the water was colder than $4^{\circ} \mathrm{C}$, infection rate rarely exceeded $2 \%$, despite many times with plentiful hosts. Taken together, these results lead us to the hypothesis that the parasite is inhibited by low temperatures, with the corollary that cold conditions favor host blooms that can increase to high abundance and persist for long periods in the ab- 


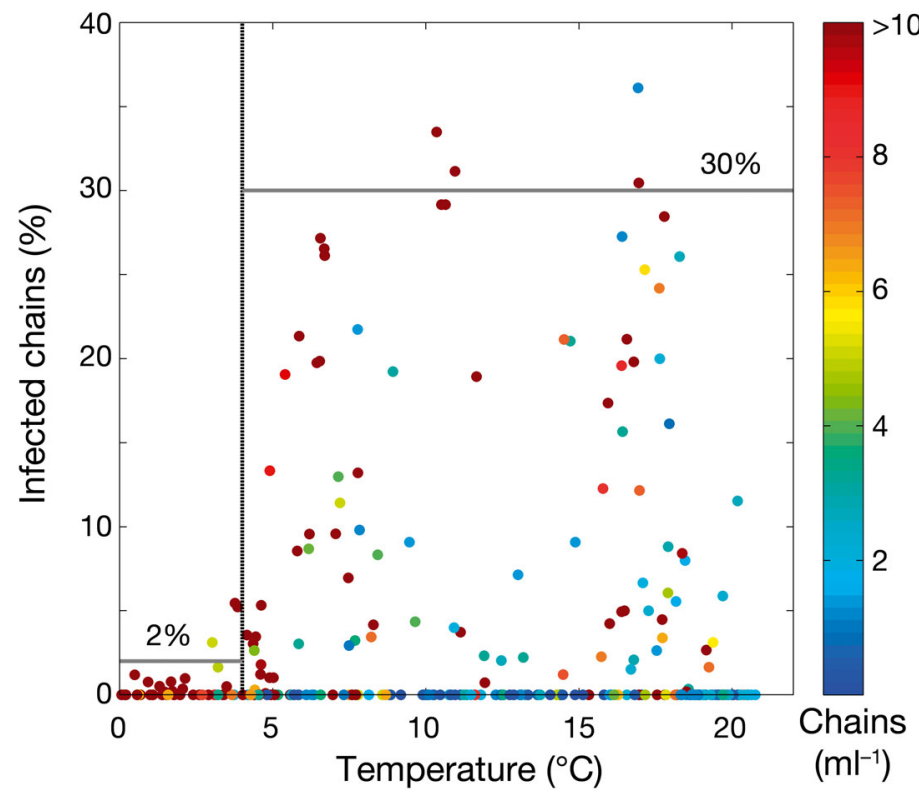

Fig. 4. Relationship between Guinardia delicatula infection and water temperature $\left({ }^{\circ} \mathrm{C}\right)$. Color scale for symbols indicates total G. delicatula abundance (chains $\mathrm{ml}^{-1}$ ). Note that all values greater than 10 chains $\mathrm{ml}^{-1}$ appear dark red (overall range extends to $\sim 120$ chains $\mathrm{ml}^{-1}$; see Fig. 2). Dashed vertical line marks $4^{\circ} \mathrm{C}$, horizontal lines mark infection rates of 2 and $30 \%$. Note that the highest infection rates only occur at temperatures $>4^{\circ} \mathrm{C}$

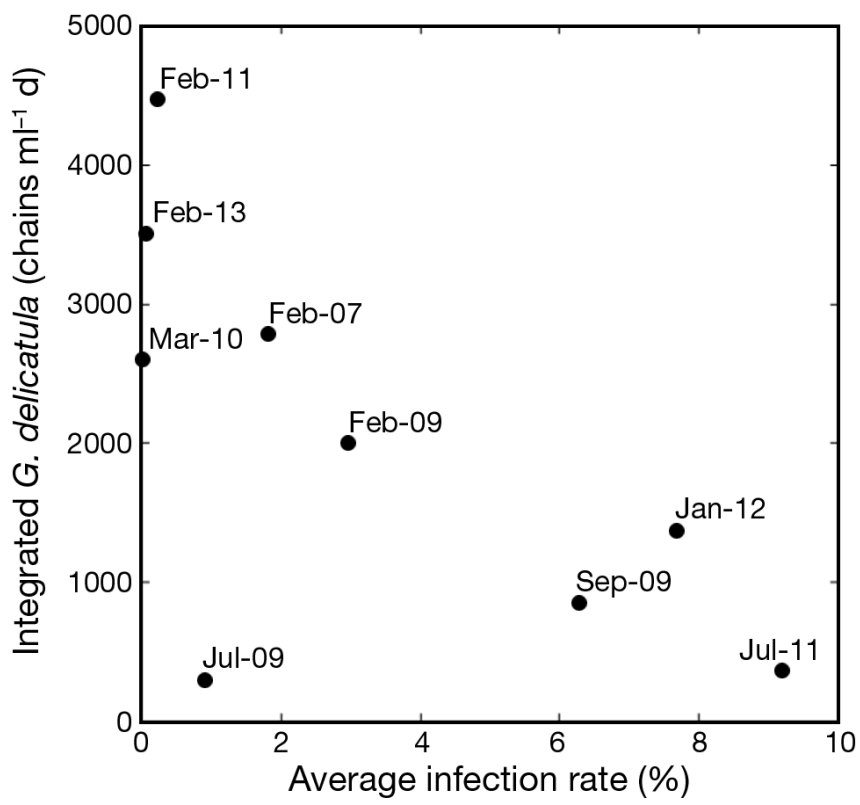

Fig. 5. Relationship between magnitude of Guinardia delicatula blooms (integrated abundance) and average infection rate $(r=-0.67, p=0.025$, considering all data points including summer 2009). Date labels indicate midpoint for each event by year and month. Blooms in 2008 were excluded due to data gaps during the events sence of parasite-induced losses. In fact, our time series results are consistent with this hypothesis; winter periods with more evidence of parasite attack generally had reduced G. delicatula blooms (Figs. 2 \& 5). Interestingly, this conclusion is similar to findings of Ibelings et al. (2011), who studied chytrid parasites of the diatom Asterionella formosa in a freshwater lake; in that system, they observed almost no infection at water temperatures $<3^{\circ} \mathrm{C}$, and corresponding evidence for boom-bust cycles of host and parasite only in years with cold winters or early spring periods.

Diatom blooms are expected to be influenced by a variety of processes, notably those that control availability of light and nutrients as they impact growth physiology and those that control interactions with predators of different types. For G. delicatula, in particular, extended time series studies in the North Sea have documented changes in bloom timing and duration that appear related in different ways to temperature, water transparency, nutrient concentrations, biomass of certain mesozooplankton, and potential size of an overwintering resting stage pool (Wiltshire et al. 2010, Schlüter et al. 2012). The net impact in that system, where G. delicatula blooms are typical in spring through fall, has been a multidecade trend of increase in its contribution to the phytoplankton community. For New England Shelf waters, where G. delicatula occurs principally in winter, our results suggest that parasite presence is a major factor controlling blooms in recent years. We found a significant negative relationship between bloom magnitude and average infection rate during the event (Fig. 5). In our time series, the record warm winter of 2012 was the only one warm enough to allow the parasites to maintain consistent levels of infection throughout the winter; this year had a very small winter bloom more consistent with typical summer events. In contrast, the cold winters of 2011 and 2013 had very low parasite incidence and supported the largest $G$. delicatula blooms in the record, while the winters of 2007 and 2009 were intermediate in terms of both infection rate and bloom magnitude. A smaller bloom than might be predicted on the basis of parasite presence occurred in summer 2009, suggesting that some other factor must have limited the magnitude of that bloom. Notably, we observed no large-magnitude blooms unless infection rate was low. Considering all events except the summer 2009 bloom (outlier, $\mathrm{p}=0.011$ ), infection rate explains $80 \%$ of the variance in bloom magnitude $\left(\mathrm{r}^{2}=0.80, \mathrm{p}=\right.$ 0.001). Future experimental and process studies are needed to address the ways that these kinds of infection impacts may interact with other types of biologi- 
cal and ecological factors that influence G. delicatula both on the New England shelf and in other regions.

As in many ocean regions, our study area shows high interannual variability, but also a significant increasing trend in water temperatures over recent decades (Nixon et al. 2004). Looking forward as temperatures continue to rise, winter periods of water below $4^{\circ} \mathrm{C}$ will shorten or disappear. These factors suggest the possibility that parasite impacts on species such as G. delicatula may increase, with immediate impacts on their population dynamics. Longer time series that encompass more warm winters will be needed to evaluate this idea. If the pattern persists, ultimately, this could alter the diatom community structure in these temperate waters where $G$. delicatula is currently a major component of the phytoplankton.

Acknowledgements. This work was supported by grants from NSF's Ocean Technology and Interdisciplinary Coordination program, NASA's Ocean Biology and Biogeochemistry program and Biodiversity and Ecological Forecasting program, the Gordon and Betty Moore Foundation, and the National Ocean Partnership Program. We are indebted to the MVCO Operations Team, especially Janet Fredericks, Jay Sisson, and Hugh Popenoe, for their dedication and skill. Alexi Shalapyonok and Taylor Crockford provided excellent technical and logistical support, and Joe Futrelle enabled exceptional informatics solutions to the challenges of dealing with hundreds of millions of images.

\section{LITERATURE CITED}

Austin T, Edson J, McGillis W, von Alt C and others (2000) The Martha's Vineyard Coastal Observatory: a long term facility for monitoring air-sea processes. Proc OCEANS 2000 MTS/IEEE Conference and Exhibition, Providence, RI, p 1937-1941

Breiman L (2001) Random forests. Mach Learn 45:5-32

Brosnahan ML, Farzan S, Keafer BA, Sosik HM, Olson RJ, Anderson DM (2013) Complexities of bloom dynamics in the toxic dinoflagellate Alexandrium fundyense revealed through DNA measurements by imaging flow cytometry coupled with species-specific rRNA probes. Deep-Sea Res II. doi:10.1016/j.dsr2.2013.05.034

- Brussaard CPD, Kuipers B, Veldhuis MJW (2005) A mesocosm study of Phaeocystis globosa population dynamics I. Regulatory role of viruses in bloom control. Harmful Algae 4:859-874

> Campbell L, Olson RJ, Sosik HM, Abraham A, Henrichs DW, Hyatt CJ, Buskey EJ (2010) First harmful Dinophysis (Dinophyceae, Dinophysiales) bloom in the U.S. is revealed by automated imaging flow cytometry. J Phycol 46:66-75

Campbell L, Henrichs D, Olson R, Sosik H (2013) Continuous automated imaging-in-flow cytometry for detection and early warning of Karenia brevis blooms in the Gulf of Mexico. Environ Sci Pollut Res Int 20: 6896-6902

Canter HM, Lund JWG (1948) Studies on plankton parasites. New Phytol 47:238-261
Chambouvet A, Morin P, Marie D, Guillou L (2008) Control of toxic marine dinoflagellate blooms by serial parasitic killers. Science 322:1254-1257

> Coats DW, Park MG (2002) Parasitism of photosynthetic dinoflagellates by three strains of Amoebophrya (Dinophyta): parasite survival, infectivity, generation time, and host specificity. J Phycol 38:520-528

> Drebes G, Schnepf E (1982) Phagotrophy and development of Paulsenella cf. chaetoceratis (Dinophyta), an ectoparasite of the diatom Streptotheca thamesis. Helgol Meeresunters 35:501-515

> Drebes G, Schnepf E (1988) Paulsenella chatton (Dinophyta), ectoparasites of marine diatoms: development and taxonomy. Helgol Meeresunters 42:563-581

> Drebes G, Schnepf E (1998) Gyrodinium undulans Hulburt, a marine dinoflagellate feeding on the bloom-forming diatom Odontella aurita, and on copepod and rotifer eggs. Helgol Meeresunters 52:1-14

> Drebes G, Kühn SF, Gmelch A, Schnepf E (1996) Cryothecomonas aestivalis sp. nov., a colourless nanoflagellate feeding on the marine centric diatom Guinardia delicatula (Cleve) Hasle. Helgol Meeresunters 50:497-515

Fredericks JJ, Trowbridge JH, Austin TC, Sosik HM, Olson RJ, Traykovski PA (2006) Martha's Vineyard Coastal Observatory: existing infrastructure for interdisciplinary science. Proc IEEE 4th International Workshop on Scientific Use of Submarine Cables and Related Technologies, Dublin

Gachon CMM, Sime-Ngando T, Strittmatter M, Chambouvet A, Kim GH (2010) Algal diseases: spotlight on a black box. Trends Plant Sci 15:633-640

Ibelings BW, Gsell AS, Mooij WM, Van Donk E, Van Den Wyngaert S, De Senerpont Domis LN (2011) Chytrid infections and diatom spring blooms: paradoxical effects of climate warming on fungal epidemics in lakes. Freshw Biol 56:754-766

> Kim D, Kim JF, Yim JH, Kwon SK, Lee CH, Lee HK (2008) Red to red-the marine bacterium Hahella chejuensis and its product prodigiosin for mitigation of harmful algal blooms. J Microbiol Biotechnol 18:1621-1629

Kühn SF, Drebes G, Schnepf E (1996) Five new species of the nanoflagellate Pirsonia in the German Bight, North Sea, feeding on planktic diatoms. Helgol Meeresunters 50:205-222

> Menden-Deuer S, Lessard EJ (2000) Carbon to volume relationships for dinoflagellates, diatoms, and other protist plankton. Limnol Oceanogr 45:569-579

> Moberg EA, Sosik HM (2012) Distance maps to estimate cell volume from two-dimensional plankton images. Limnol Oceanogr Methods 10:278-288

> Montagnes DJS, Chambouvet A, Guillou L, Fenton A (2008) Responsibility of microzooplankton and parasite pressure for the demise of toxic dinoflagellate blooms. Aquat Microb Ecol 53:211-225

> Nixon S, Granger S, Buckley B, Lamont M, Rowell B (2004) A one hundred and seventeen year coastal water temperature record from Woods Hole, Massachusetts. Estuaries 27:397-404

Olson RJ, Sosik HM (2007) A submersible imaging-in-flow instrument to analyze nano- and microplankton: Imaging FlowCytobot. Limnol Oceanogr Methods 5:195-203

Olson RJ, Shalapyonok A, Sosik HM (2003) An automated submersible flow cytometer for analyzing pico- and nanophytoplankton: FlowCytobot. Deep-Sea Res I 50:301-315 > Park MG, Yih W, Coats DW (2004) Parasites and phyto- 
plankton, with special emphasis on dinoflagellate infections. J Eukaryot Microbiol 51:145-155

Schlüter MH, Kraberg A, Wiltshire KH (2012) Long-term changes in the seasonality of selected diatoms related to grazers and environmental conditions. J Sea Res 67: 91-97

Schnepf E, Drebes G, Elbrächter M (1990) Pirsonia guinardiae, gen. et spec. nov.: A parasitic flagellate on the marine diatom Guinardia flaccida with an unusual mode of food uptake. Helgol Meeresunters 44:275-293

Scholin C, Jensen S, Roman B, Massion E and others (2006) The Environmental Sample Processor (ESP - An autonomous robotic device for detecting microorganisms remotely using molecular probe technology. Proc OCEANS 2006, Boston, MA, p 1-4

Sieracki CK, Sieracki ME, Yentsch CS (1998) An imagingin-flow system for automated analysis of marine microplankton. Mar Ecol Prog Ser 168:285-296

Sime-Ngando T (2012) Phytoplankton chytridiomycosis:

Editorial responsibility: Toshi Nagata,

Kashiwanoha, Japan fungal parasites of phytoplankton and their imprints on the food web dynamics. Front Microbiol 3:361

Sosik HM, Olson RJ (2007) Automated taxonomic classification of phytoplankton sampled with imaging-in-flow cytometry. Limnol Oceanogr Methods 5:204-216

Sosik H, Olson R, Armbrust EV (2010) Flow cytometry in phytoplankton research. In: Suggett DJ, Prášil O, Borowitzka MA (eds) Chlorophyll a fluorescence in aquatic sciences: methods and applications, Book 4. Springer, Dordrecht, p 171-185

Tillmann U, Hesse KJ, Tillmann A (1999) Large-scale parasitic infection of diatoms in the Northfrisian Wadden Sea. J Sea Res 42:255-261

Van Donk E (1989) The role of fungal parasites in phytoplankton succession. In: Sommer U (ed) Plankton ecology. Springer, Berlin, p 171-194

Wiltshire K, Kraberg A, Bartsch I, Boersma M and others (2010) Helgoland Roads, North Sea: 45 years of change. Estuaries Coasts 33:295-310

Submitted: November 27, 2013; Accepted: March 13, 2014 Proofs received from author(s): April 7, 2014 